\title{
POTOCCY HERBU PILAWA JAKO DOWÓDCY SIŁ ZBROJNYCH ZIEMI HALICKIEJ W XVII WIEKU
}

\author{
Dariusz Kupisz (D) http://orcid.org/0000-0002-9912-944X \\ Uniwersytet Marii Curie-Skłodowskiej w Lublinie
}

\author{
ABSTRACT \\ THE POTOCKI FAMILY OF THE PILAWA COAT OF ARMS AS \\ THE MILITARY LEADERS OF HALYCH LAND ARMED FORCES \\ IN THE $17^{\text {TH }}$ CENTURY
}

In the $17^{\text {th }}$ century the local parliaments of the Polish-Lithuanian Commonwealth were tasked with various military duties ranging from defensive capability matters, including self-defence of their own land or voivodeship, to the defence of the country borders. It often enough required raising the levy in great numbers or forming regular armed forces and appointing commanders of these troops. The article presents the actions such as appointing members of the local noble families as the commanders in chief that were undertaken by the dietines (sejmiki) of Halych Land in the $17^{\text {th }}$ century. As it turns out, this leadership was most often granted to the members of the Potocki family, which resulted from a number of factors, among others, their long term settlement in this region, the local offices they held, their military expertise and last but not least, their significant wealth. The nobles who gathered during the local government sessions expected that the Potocki family would be able to fulfil duties imposed on them, and if needed they would support soldiers at their expense until the dietines reimbursed expenses incurred by them.

Keywords: nobility, dietines, Old-Polish military affairs, Halych Land.

Słowa kluczowe: szlachta, sejmiki, wojskowość staropolska, ziemia halicka.

W przedrozbiorowej Rzeczypospolitej wpływ szlachty na obronność kraju przejawiał się na kilku płaszczyznach: w uczestnictwie w pospolitym ruszeniu, służbie w wojskach zaciężnych, wreszcie w uchwalaniu podatków na wojsko (na sejmie lub sejmiku). Wzrost znaczenia i poszerzenie kompetencji sejmików ziemskich doprowadziły w XVII wieku do formowania przez nie tak zwanych wojsk powiatowych oraz organizacji wypraw łanowych i dymowych. Formacje te, zaliczane do regularnych 
sił zbrojnych, były wystawiane przez samorządy szlacheckie obok tradycyjnego pospolitego ruszenia.

Pospolite ruszenie, zaliczane do nieregularnych formacji zbrojnych, obejmowało wszystkich posiadaczy dóbr ziemskich z wyjątkiem fundacji kościelnych. W przypadku tak zwanej ekspedycji generalnej, przeznaczonej do obrony całego kraju, było zwoływane przez króla za zgodą sejmu. Istniała również możliwość zwołania pospolitego ruszenia jednego województwa lub ziemi przez lokalnych urzędników. Pospolite ruszenie poprzedzał sejmik bądź popis, na którym ustalano sprawy organizacyjne. Zgodnie z prawem szlachtą danego województwa kierowali miejscowy wojewoda i kasztelanowie, w praktyce nie zawsze mogli się oni podjąć tego zadania, toteż niejednokrotnie wybierano na ich miejsce rotmistrzów oraz pułkownika (duktora) ${ }^{1}$.

Oddziały powiatowe były tworzone systemem zaciężnym i uzbrajały się oraz wyposażały na takiej samej zasadzie jak inne ówczesne jednostki zaciężne (kozackie, husarskie, dragońskie itp.). Tworzono je na podstawie uchwał sejmików (czasem poprzedzonych konstytucjami sejmowymi). Na sejmiku określano zwykle rodzaj oraz liczbę żołnierzy, cel, dla jakiego ich zaciągano, czas służby i przepisy dyscyplinarne. Szlachta wybierała spośród siebie dowódców poszczególnych jednostek, decydowała o podatkach na opłacenie wojska oraz określała wynagrodzenie żołnierzy i oficerów. Oddziały powiatowe formowano jako uzupełnienie armii koronnej bądź litewskiej i posyłano pod rozkazy hetmanów lub dla własnych potrzeb województwa, ziemi, a nawet powiatu ${ }^{2}$.

Udział sejmiku w procesie formowania wypraw łanowych i dymowych oraz nominowaniu ich kadry oficerskiej był taki sam jak w wypadku wojska powiatowego. Tyle tylko, że z założenia żołnierz wyprawny miał być wystawiany przez posiadaczy dóbr ziemskich oraz miasta $\mathrm{z}$ określonej w uchwałach sejmowych ilości łanów lub dymów. W praktyce zdarzało się, że zamiast tego zaciągano żołnierzy lub proszono miejscowych dygnitarzy o wystawienie swych nadwornych rot w miejsce łanowych. $\mathrm{Z}$ reguły wyprawy lanowe i dymowe formowano na potrzeby obrony kraju w miejsce pospolitego ruszenia, ale zdarzało się, że wystawiano je obok pospolitego ruszenia lub jako oddziały samoobrony terytorialnej ${ }^{3}$.

Wszystkie z wymienionych tu formacji zbrojnych organizowano wielokrotnie w XVII wieku na terenie województwa ruskiego, w tym także na obszarze wchodzącej w jego skład ziemi halickiej, posiadającej swój odrębny sejmik. Jedną z bardziej wpływowych, by nie powiedzieć dominujących rodzin działających na forum sejmiku halickiego byli bez wątpienia Potoccy herbu Pilawa. Celem niniejszego artykułu

${ }^{1}$ J. Wimmer, Wojsko polskie $w$ drugiej polowie XVII wieku, Warszawa 1965, s. 20; por. też: L.A. Wierzbicki, Pospolite ruszenie w Polsce $w$ drugiej polowie XVII wieku. Ostatnie wyprawy z lat 1670-1672, Lublin 2011.

${ }^{2}$ D. Kupisz, Wojska powiatowe samorządów Matopolski i Rusi Czerwonej w latach 1572-1717, Lublin 2008, s. 134.

3 J. Gerlach, Żotnierz łanowy i dymowy w Polsce feudalnej, „Sprawozdania Towarzystwa Naukowego w Toruniu” 1952, nr 6, z. 1-4, s. 77-78; T. Ciesielski, Wyprawa łanowa 1653 r., „Zeszyty Naukowe Wyższej Szkoły Pedagogicznej im. Powstańców Śląskich w Opolu. Historia” 1994, t. 30, s. 43-44. Szerzej na ten temat zob. D. Kupisz, Wyprawy żotnierza łanowego w Koronie w czasach Jana Kazimie$r z a$, Warszawa 2018. 
jest przedstawienie ich udziału w organizacji przez sejmik halicki oddziałów zbrojnych, zarówno tych wystawianych na potrzeby kraju, jak i formowanych z myślą o zapewnieniu bezpieczeństwa własnej ziemi.

Pierwsze wzmianki dotyczące związków Potockich z formacjami zbrojnymi ziemi halickiej można powiązać ze skutkami wypraw mołdawskich z lat 1612-1616. Obawiając się odwetu Mołdawian i Tatarów, szlachta halicka uchwaliła pod koniec 1615 roku pospolite ruszenie, wybierając na rotmistrza powiatu trembowelskiego wojewodzica bracławskiego Mikołaja Potockiego. Wśród szlachty halickiej doszło jednak do konfliktu, który zaowocował „rozdwojeniem” sejmiku, i nie wiadomo, czy uchwała została zrealizowana ${ }^{4}$. Pierwszym z Potockich, o którym wiadomo, że dowodził regularnym wojskiem zaciężnym organizowanym przez tamtejszy samorząd szlachecki, był Stefan, starosta feliński. Obawiając się agresji tureckiej, ziemia halicka zastrzegła sobie w 1618 roku wydatkowanie części podatków na chorągwie powiatowe. Starosta feliński został wówczas wybrany przez sejmik zebrany w Haliczu jednym z rotmistrzów owych zaciągów. Wiadomo, że poborcy przekazali Potockiemu pieniądze na zaciągi, ten jednak nie stworzył nowej jednostki, lecz przekształcił w powiatową swą prywatną chorągiew jazdy. Dokonał tego za zgodą miejscowej szlachty, która zresztą kazała mu w pierwszej kolejności dbać o ochronę ziemi halickiej przed spodziewanymi czambułami tatarskimi $i^{5}$. Niestety nie znamy liczebności chorągwi Potockiego, nic też nie wiadomo o działaniach bojowych podkomendnych starosty.

$\mathrm{O}$ wiele szersze zaangażowanie Potockich w formowanie i działalność wojsk powiatowych można zaobserwować począwszy od wybuchu powstania Chmielnickiego. W obliczu zagrożenia kozackiego szlachta ziemi halickiej uprosiła 17 czerwca 1648 roku wojewodę podolskiego Stanisława Potockiego (późniejszego hetmana Rewerę), aby objął funkcję pułkownika zaciągów ziemi halickiej liczących 400 jazdy i 100 piechoty $^{6}$. Został on ponadto rotmistrzem jedynej halickiej chorągwi husarskiej i miał wyznaczyć dowódcę roty pieszej, choć najprawdopodobniej zamiast niej zaciągnięto dragonię. $Z$ kolei rotmistrzem jednej z trzech chorągwi kozackich został wówczas najstarszy syn pułkownika - starosta halicki Andrzej Potocki (pozostałymi dowodzili Aleksander Cetner i Michał Kuropatwa). Dowódcom liczono służbę od daty sejmiku, a miejsce popisu chorągwi miał wyznaczyć Stanisław Potocki, i to on odpowiadał za liczebność, uzbrojenie i dyscyplinę w oddziałach. Początkowo przewidywano jedynie kwartał służby, ale ostatecznie przedłużono ją na dwie ćwierci roku?

Warto zauważyć, że pułkownik zaciągów halickich Stanisław Potocki został jednocześnie włączony do grona 32 komisarzy przydanych przez sejm konwokacyjny

${ }^{4}$ Laudum ziemi halickiej z 1 XII 1615 r., Akta grodzkie i ziemskie z czasów Rzeczypospolitej Polskiej $z$ archiwum tak zwanego bernardyńskiego we Lwowie [dalej: AGZ], t. 24: Lauda sejmikowe halickie 1575-1695, wyd. A. Prochaska, Lwów 1931, s. 29.

${ }^{5}$ Biblioteka Naukowa Polskiej Akademii Umiejętności i Polskiej Akademii Nauk w Krakowie [dalej: BPAU-PAN w Krakowie], rkps 1051, Instrukcja ziemi halickiej z 2 I 1618 r.; Laudum ziemi halickiej z 7 V 1618 r., k. 102-102v; AGZ, t. 24, s. 30.

${ }^{6}$ A. Borowiak, Wojsko powiatowe przed kampania pitawiecka 1648 roku [w:] Studia nad staropolska sztuka wojenna, t. 2, red. Z. Hundert, Oświęcim 2013, s. 148, 158.

${ }^{7}$ D. Kupisz, Wojska powiatowe..., s. 396, tu omyłkowo podano 500 zamiast 400 jazdy. 
do boku regimentarzy wyznaczonych na wodzów armii ${ }^{8}$. Bez wątpienia był jednym z bardziej doświadczonych dowódców mających za sobą udział w licznych kampaniach wojennych. Zdołał też bardzo szybko zrealizować uchwałę sejmiku halickiego i podległe mu oddziały powiatowe zaczęły działać już w lipcu 1648 roku, zwalczając podjazdy kozackie zapuszczające się na tereny województwa ruskiego9. Sam wojewoda zajął natomiast wyczekujące stanowisko wobec sporu o miejsce koncentracji armii koronnej, jaki wybuchł pomiędzy regimentarzami a księciem Jeremim Wiśniowieckim. Pojawił się z pułkiem ziemi halickiej i swymi prywatnymi oddziałami koło obozów zwaśnionych stron, ale stanął w odrębnych stanowiskach. Dopiero 9 września, zapewne pod wpływem Aleksandra Koniecpolskiego, połączył się z siłami regimentarzy wyznaczonych przez sejm - Dominika Zasławskiego i Jana Ostroroga ${ }^{10}$.

Uważa się, że Stanisław Potocki nie brał bezpośredniego udziału w walkach pod Piławcami, ponieważ wraz z wojewodą brzesko-kujawskim Janem Szczawińskim dowodził odwodami ${ }^{11}$. Tymczasem 23 września 1648 roku podległe mu chorągwie powiatowe ziemi halickiej walczyły z Kozakami, ponosząc przy tym znaczne straty. Podobnie jak inne jednostki opuściły pole bitwy w panice, ale nie wszystkie zostały rozbite. Być może żołnierze podążyli za swym pułkownikiem do Lwowa. Nic jednak nie wiadomo o ich działalności w pierwszych tygodniach po klęsce piławieckiej. Stanisław Potocki uczestniczył w listopadzie w elekcji Jana Kazimierza, a potem pojawił się na sejmie koronacyjnym nowego monarchy. Niektórzy rotmistrzowie haliccy zdołali natomiast utrzymać pod swą komendą część ludzi i po wycofaniu się wojsk kozackich w głąb Ukrainy powrócili do województwa ruskiego. Zaczęli nawet samorzutnie tłumić bunty wybuchające wśród ludności okolicznych miast i wsi, ale wiadomo, że pod koniec 1648 roku kończył się im okres służby ${ }^{12}$.

W 1649 roku wojewoda podolski Stanisław Potocki stanął po raz drugi na czele wojska powiatowego. Szlachta zebrana w Haliczu 15 marca tego roku uznała, że po ustąpieniu zagonów kozackich jedynie własne wojsko powiatowe zagwarantuje przywrócenie ładu i porządku w tej części województwa ruskiego. Potocki jako „regimentarz powiatowy" zaciągnął z jej ramienia 8 chorągwi kozackich, po 100 koni każda, i jedną pieszą w liczbie 100 ludzi. Nie bez wpływu wojewody podolskiego wybrano rotmistrzów, między innymi wojewodzica bracławskiego Jana Potockiego, a i samemu regimentarzowi powierzono komendę nad jedną z chorągwi kozackich (z pewnością nie dowodził nią bezpośrednio). Podobnie jak w poprzedniej uchwale zabroniono dowódcom zaciągania do wojska powiatowego Rusinów, Wołochów,

${ }^{8}$ Volumina Constitutionum, t. 4, vol. 1, oprac. S. Grodziski, M. Kwiecień, K. Fokt, Warszawa 2015, s. 133-134.

9 Sprawy i rzeczy ukraińskie. Materiały do dziejów kozaczyzny i hajdamaczyzny, wyd. F. Rawita-Gawroński, Lwów 1914, s. 94-97; D. Kupisz, Wojska powiatowe..., s. 254, przyp. 229.

${ }^{10}$ Relacje wojenne z pierwszych lat walk polsko-kozackich powstania Bohdana Chmielnickiego okresu ,Ogniem i mieczem” (1648-1651), oprac. M. Nagielski, Warszawa 1999, s. 128-129.

${ }^{11}$ A. Przyboś, Potocki Stanisław zwany Rewera [w:] Polski stownik biograficzny [dalej: PSB], t. 28, Wrocław-Warszawa-Kraków 1984-1985, s. 142-145.

${ }^{12}$ D. Kupisz, Wojska powiatowe..., s. 257. 
Czerkasów i wszelkich ludzi uznanych za „niepewnych”. Regimentarzowi polecono, aby rozsyłał oddziały po całej ziemi halickiej, a pułk liczący 900 żołnierzy koncentrował jedynie w wypadku groźniejszych rozruchów lub wtargnięcia większych gromad rozbójników spoza granicy ${ }^{13}$.

Działalność oddziałów powiatowych ziemi halickiej w 1649 roku została już omówiona szczegółowo w literaturze przedmiotu ${ }^{14}$, poprzestaniemy więc tu na przypomnieniu najważniejszych kwestii. Rozpoczęły one służbę 1 kwietnia, pacyfikując zrewoltowaną ludność oraz zwalczając bandy wdzierające się na teren ziemi halickiej. Operowały w ugrupowaniach składających się najczęściej z dwóch chorągwi, dzięki czemu mogły pojawiać się w wielu miejscach ochranianego terytorium. Szukały sprawców przestępstw oraz byłych i aktualnych buntowników otaczając wsie i miasteczka tak, aby odciąć wszystkie drogi odwrotu. Przebieg większości akcji świadczy o tym, że były to typowe akcje pacyfikacyjne, obliczone na sterroryzowanie ludności oraz wyeliminowanie przywódców buntu sprzed roku. Starano się je przeprowadzać przez zaskoczenie, czasami nocą, co w połączeniu z otaczaniem wsi, wyłapywaniem i spędzaniem w jedno miejsce mieszkańców prowadziło do oskarżeń o stosowanie tatarskich metod działania. Obejścia przywódców buntów i pojedynczych zbiegów palono, natomiast odwetowe palenie całych wsi należało do rzadkości. Aby blokada miejscowości i wyłapywanie winnych były skuteczniejsze, jako przewodników oraz informatorów wykorzystywano mieszkańców sąsiednich miejscowości, którzy niekiedy wspomagali żołnierzy czynnie. Warto zauważyć, że wśród tych ostatnich znajdowali się wielokrotnie mieszczanie Potoka, należącego do Pilawitów Potockich ${ }^{15}$.

Księgi grodzkie halickie i trembowelskie z lat 1649-1650 są pełne skarg skierowanych przeciw żołnierzom powiatowym, ale też koronnym Aleksandra Cetnera i Aleksandra Koniecpolskiego oraz prywatnym Jana „Sobiepana” Zamoyskiego, działającym wówczas na tym terenie ${ }^{16}$. Spośród wszystkich jednostek to właśnie oddziały powiatowe starały się unikać zbyt drastycznych represji, mając na względzie współobywateli ziemi halickiej. Szlachta zasypywała rotmistrzów halickich pozwami w obronie swych poddanych nawet wtedy, gdy ci atakowali żołnierzy ${ }^{17}$. Regimentarz Stanisław Potocki nie chciał się chyba narażać na niechęć wśród miejscowej szlachty ze względów politycznych. Co ciekawe, w księgach sądowych ziemi halickiej nie odnaleziono ani jednego pozwu skierowanego bezpośrednio przeciwko niemu!

${ }^{13}$ Laudum ziemi halickiej z 15 III 1649 r., AGZ, t. 24, s. 75-77.

${ }^{14}$ D. Kupisz, Wojska powiatowe..., s. 329-332; S. Tomašivskij, Narodni ruchy v halickij Rusy 1648 g, Lviv 1898, s. 107-108; W. Łoziński, Prawem i lewem. Obyczaje na Czerwonej Rusi w pierwszej połowie XVII wieku, t. 1, Kraków 1957, s. 359-360.

${ }^{15}$ Центральний державний історичний архів України, Львів [Centralne Państwowe Archiwum Historyczne Ukrainy we Lwowie, dalej: CPAHUL], fond 5, op. 1, nr 141, s. 1297-1300, 1338-1344, 17111736; ibidem, nr 142, Pozwy i protestacje przeciw choragwiom halickim z IV-IX 1649 r., s. 323-325.

${ }^{16}$ A. Czołowski, Z dziejów chmielniczyzny na Podkarpaciu [w:] Księga pamiątkowa ku czci Władystawa Abrahama, t. 2, Lwów 1931, s. 396-398.

${ }^{17}$ Głośne stało się pobicie Łukasza Trąmpczyńskiego spod chorągwi Stanisława Potockiego przez własnych poddanych oraz kilku przedstawicieli drobnej szlachty ruskiej. Zob. S. Tomašivskij, op. cit., s. 110 . 
Wojewoda Stanisław Potocki nie przebywał zapewne przy swych oddziałach przez cały okres ich służby, ale informacje $w$ jednym $z$ jego biogramów, jakoby w czerwcu 1649 roku był przy królu w Warszawie i wraz z nim wyruszył na kampanię zborowską ${ }^{18}$, nie są zgodne ze źródłami. 15 czerwca regimentarz ziemi halickiej był pod Podhajcami, skąd wydawał rozkazy swym rotmistrzom powiatowym, kierując część z nich bliżej granicy z Mołdawią i Siedmiogrodem. Przekraczały ją wówczas liczne bandy tak zwanych opryszków ${ }^{19}$. W pierwszych dniach lipca pojawił się natomiast pod Haliczem i w obliczu pochodu armii kozacko-tatarskiej skoncentrował tu wszystkie podległe sobie chorągwie powiatowe. Potocki prowadził stąd działania rozpoznawcze, posyłając swych podkomendnych nawet w okolice Zbaraża, pod który podchodzili wówczas Kozacy i Tatarzy ${ }^{20}$. Pod Haliczem zdecydowano też, za aprobatą monarchy, że miejscowe pospolite ruszenie pozostanie na straży ziemi pod komendą podkomorzego Jana Teodoryka Potockiego. W zamian za to, w sukurs armii królewskiej maszerującej na odsiecz Zbaraża, posłano pułk wojska powiatowego ziemi halickiej ${ }^{21}$. Stanisław Potocki musiał wyruszyć spod Halicza pod koniec lipca, zdołał bowiem dotrzeć do armii królewskiej i wraz ze swymi podkomendnymi odznaczył się w czasie bitwy pod Zborowem ${ }^{22}$.

Pod Zborowem halickie oddziały powiatowe poniosły znaczne straty, jednak po kampanii powróciły do swej ziemi i kontynuowały tu działania pacyfikacyjne. Zostały rozwiązane 31 października 1649 roku i tym samym Stanisław Potocki zakończył swoją działalność na stanowisku regimentarza pułku ziemi halickiej. Sejmik halicki docenił jego postawę podczas walk z Kozakami, a w szczególności zasługi w batalii zborowskiej (w instrukcji danej posłom na sejm zalecił przedstawić go królowi do nagrody). Jak wiadomo, Potocki został wkrótce hetmanem polnym, a następnie wielkim koronnym. Doceniono również zasługi innych Potockich walczących w tej kampanii - wojewodzica bracławskiego Jana oraz kasztelanica krakowskiego Mikołaja. Warto również zauważyć, że wojewodzic Jan Potocki, dowodzący w 1649 roku jedną z chorągwi kozackich ziemi halickiej, został wraz z nią włączony w skład armii koronnej. Tyle tylko, że zwrot zaległego żołdu za kampanię zborowską otrzymał od sejmiku halickiego dopiero 10 lat później²3.

Nie wiadomo, jak przedstawiał się udział szlachty halickiej w wyprawie beresteckiej 1651 roku. Z pewnością Potoccy uczestniczyli w niej, nie tylko z racji służby w wojskach koronnych, lecz także w pospolitym ruszeniu. Być może dowodzili jedną z czterech chorągwi opłaconych przez sejmik halicki na wyprawę spod

${ }^{18}$ A. Przyboś, Potocki Stanisław zwany Rewera..., s. 142.

19 Archiwum Narodowe w Krakowie, Zbiór Rusieckich [dalej: ANK, ZR], sygn. 41, List S. Potockiego do podstarościego śniatyńskiego, w Podhajcach 15 VI 1649 r., s. 135.

${ }^{20}$ APK, ZR, sygn. 41, List S. Potockiego do podsędka lwowskiego, w obozie pod Haliczem 5 VII 1649 r., s. 131.

${ }^{21}$ Relacje wojenne..., s. 328, wymieniają 500 żołnierzy przybyłych ze Stanisławem Potockim, ale o 900 wspomina Jakuba Michałowskiego, wojskiego lubelskiego a później kasztelana bieckiego księa pamiętnicza z dawnego rękopisma będacego własnością Ludwika hr. Morsztyna, wyd. A.Z. Helc el, Kraków 1864, s. 427.

${ }^{22}$ Instrukcja ziemi halickiej z 6 X 1649 r., AGZ, t. 24, s. 83.

${ }^{23}$ Ibidem, s. 81-82, 158. 
Beresteczka pod Białą Cerkiew, a dowódcą mógł być wspomniany wyżej wojewodzic bracławski ${ }^{24}$.

Przez wiele lat z formacjami zbrojnymi samorządu szlacheckiego ziemi halickiej był związany syn Stanisława Rewery - starosta halicki Andrzej Potocki. W późniejszym okresie także on został hetmanem koronnym. Jak wspomniano, rotmistrzował jednej z chorągwi halickich pod komendą ojca w 1648 roku, od tego czasu do końca życia trzymał też rotmistrzostwo różnych chorągwi komputowych. W działalność wojskową samorządu szlacheckiego zaangażował się aktywniej w 1655 roku, kiedy to sejmik halicki zlecił mu organizację wyprawy łanowej. Najprawdopodobniej był obecny na sejmiku w Haliczu 22 kwietnia tego roku i wywarł wpływ na uchwałe dotyczącą wyprawy piechura z 10 łanów na dwa kwartały „dla suplementowania wojska koronnego". Miał to być żołnierz w barwie błękitnej, ale kroju niemieckiego, „z muszkietem lontowym, prochu na jednego funtów dziesięć, ołowiu dwadzieścia z lontami, rydlem, motyką, toporem podgórskim, szablą". Szlachta wyznaczyła popis piechurów łanowych już na 1 czerwca, stąd z braku czasu nie była w stanie znaleźć dla nich odpowiedniego kapitana i innych oficerów. Upoważniła więc starostę halickiego do nominowania na te stanowiska osób z odpowiednim doświadczeniem wojskowym oraz godnych zaufania. Z kolejnej uchwały szlachty halickiej, podjętej 28 lipca 1655 roku, wynika, że Andrzej Potocki wywiązał się z obietnicy i wskazał rotmistrza (nie znamy jego nazwiska), który odebrał od poborcy ziemi halickiej 400 zł traktamentu. Nie przybył on jednak na sejmik i niektórzy obawiali się, że może nie stawić się na popis jednostki (przesunięty na 16 sierpnia), wybierając służbę w jednostkach komputowych. Na wszelki wypadek wybrano rotmistrza „zastępczego" w osobie Szczęsnego Jasińskiego. Jednocześnie, pod wpływem uniwersałów królewskich i wieści z zakończonego właśnie sejmu, zmniejszono obciążenie posesorów ziemi halickiej, deklarując wystawienie jednego piechura z 15 łanów. Co ciekawe, każdego z nich kazano wyposażyć w wóz z żywnością oraz dodatkowego konia „i siodło dla potrzeby jakiej”25. Wynika stąd, że piechota ziemi halickiej mogła w każdej chwili przekształcić się w dragonię, co było korzystne szczególnie na wschodnim teatrze wojny.

Jak świadczy tak zwana kombinacja łanów wsi i miast powiatu halickiego oraz trembowelskiego, komisarze bardzo szybko wywiązali się z pracy dotyczącej technicznych zasad wyprawiania piechurów ${ }^{26}$. Niestety wpisy w księgach ziemi halickiej z 1655 roku kończą się na 2 sierpnia, stąd nie wiadomo, czy odbył się popis piechoty powiatowej i czy przybył nań oficer wyznaczony przez Andrzeja Potockiego. Z uniwersału Jana Kazimierza do szlachty halickiej, wystosowanego ze Lwowa 16 marca

${ }^{24}$ Sygnalizował to M. Nagielski, Potocki Jan h. Pilawa [w:] PSB, t. 28, s. 32. Na potwierdzenie tej tezy można dodać, że jeszcze 20 lat później szlachta halicka domagała się koekwacji w podatkach z tytułu wyprawienia czterech chorągwi ,pod Kijów”. CPAHUL, fond 5, op. 1, nr 172, Instrukcja ziemi halickiej z 20 IV 1672 r., s. 696-697.

${ }^{25}$ Lauda ziemi halickiej z 22 IV 1655 r. i 28 VII 1655 r., AGZ, t. 24, s. 116-119; D. Kupisz, Wyprawy żotnierza tanowego ..., s. 148-149.

${ }^{26}$ CPAHUL, fond 5, op. 1, nr 147, Kombinacja łanów powiatu halickiego z 28 VII 1655 r., s. 1702 1713. 
1656 roku, wynika jednak, że rok wcześniej zdołała ona zorganizować piechotę łanową ,uchwaloną na ostatnim sejmie”, a dowodził nią nieznany z nazwiska kapitan ${ }^{27}$ (być może wskazany przez Potockiego).

Starosta halicki nie mógł dowodzić bezpośrednio halicką piechotą łanową, w tym okresie bowiem służył w armii koronnej. Wiosną 1656 roku zwolniono go nawet $\mathrm{z}$ tego tytułu z pospolitego ruszenia ${ }^{28}$. Tym niemniej już rok później musiał się zaangażować ponownie w organizację sił zbrojnych ziemi halickiej. Na sejmiku obradującym w Haliczu 29 maja 1657 roku uchwalono jedno podymne na zaciąg wojska powiatowego dla ochrony własnego terytorium. Miało się ono składać ze 100 jazdy kozackiej oraz oddziału piechoty o nieznanej liczebności, którym dowodził Andrzej Potocki. 26 czerwca 1657 roku podzielono jazdę na dwie chorągwie po 50 koni, przydzielając jedną do powiatu halickiego, a drugą do trembowelskiego. Podzielono też piechotę, obsadzając nią zarówno zamek halicki, jak i trembowelski, przy czym zakazano tamtejszym starostom wliczania do oddziałów powiatowych swoich milicji starościńskich. Żołnierze mieli służyć jedną ćwierć i ruszać przeciw wszelkim bandom opryszków na polecenie starosty trembowelskiego Rafała Makowieckiego lub podsędka halickiego Zygmunta Świrskiego ${ }^{29}$.

Wkrótce okazało się, że ziemi halickiej zagraża najazd wojsk siedmiogrodzkich i Kozaków, toteż Andrzej Potocki musiał się ponownie włączyć w organizację jej obrony. Ponieważ sytuacja wymagała błyskawicznego zaciągu wojska, sejmik zwołany 29 czerwca 1657 roku zwrócił się do niego o pomoc w znalezieniu odpowiednich żołnierzy. Starosta zgodził się wynająć ziemi halickiej swoich 200 prywatnych dragonów pod warunkiem pokrycia im kwartalnego żołdu. Uzgodniono, że będzie to kwota 7200 zł, która akurat znajdowała się w dyspozycji poborców, a jeśli sytuacja będzie tego wymagała, Potocki zgodzi się na dalszą służbę swych żołnierzy na rzecz samorządu. Chorągiew dragońska miała stawić się pod rozkazy króla lub hetmanów, zastępując halickie pospolite ruszenie, które w tej sytuacji mogło pozostać na terenie swych powiatów. Ponadto starosta Potocki miał otrzymać od sejmiku pewne kwoty pozostające $\mathrm{z}$ podymnego na organizację obrony zamku halickiego, w tym zaciąg oddziału piechoty. Zastrzegano jednak ponownie, że nie może do piechurów służących za pieniądze sejmiku wliczyć swych 40 żołnierzy, których utrzymuje na zamku halickim jako tamtejszy starosta ${ }^{30}$.

Andrzej Potocki zjawił się w Haliczu, gdzie zbierano wówczas podymne, rozbudowywano umocnienia i organizowano pospiesznie obronę. 11 lipca 1657 roku wezwał stąd szlachtę powiatu do zamku halickiego, donosząc, że Węgrzy maszerują już na Kołomyję i Śniatyń ${ }^{31}$. Z kolei hetman Stanisław Rewera Potocki zalecał obywatelom ziemi halickiej, aby łączyli się z nim wraz „, ludźmi stipendio ziemie i powiatów swych zaciągnionymi”. Potem jednak zmienił zdanie, nakazując, aby samodzielnie

${ }^{27}$ Ibidem, Uniwersał Jana Kazimierza do szlachty halickiej, Lwów, 16 III 1656 r., s. 1786.

${ }^{28}$ Laudum ziemi halickiej z 21 III 1656 r., AGZ, t. 24, s. 123.

${ }^{29}$ D. Kupisz, Wojska powiatowe..., s. 340.

${ }^{30}$ Laudum ziemi halickiej z 26 VI 1657 r., AGZ, t. 24, s. 132-133.

${ }^{31}$ CPAHUL, fond 5, op. 1, nr 148, Uniwersał starosty A. Potockiego, Halicz, 11 VII 1657 r., s. 203-205. 
bronili przepraw Siedmiogrodzianom. Ostatecznie zgromadzona na pospolite ruszenie szlachta schroniła się w zamkach trembowelskim i halickim, wspierając tamtejszych starostów i niewielkie oddziały piechoty powiatowej. Dragoni Andrzeja Potockiego, przekazani na służbę ziemi halickiej, zostali natomiast włączeni w skład wojsk koronnych wraz z dwoma chorągwiami powiatowej jazdy kozackiej liczącymi po 50 koni. Mimo że te ostatnie zostały zaciągnięte przez Haliczan na potrzeby obrony domowej, to jednak na prośbę monarchy zostały wysłane na front. Wszystkie trzy jednostki wzięły udział w końcowej fazie zmagań z wycofującymi się wojskami Rakoczego ${ }^{32}$. Gdy niebezpieczeństwo minęło, sejmik ziemi halickiej, obradujący 10 września 1657 roku, pokwitował starostę Andrzeja Potockiego za kwartalną służbę jego dragonów i zaciąg piechoty ${ }^{33}$.

Być może wysiłek na rzecz obrony domowej, połączony z innymi obciążeniami finansowymi, zmusił w 1658 roku sejmik halicki do zmodyfikowania zasad wystawienia oddziału piechoty łanowej na służbę Rzeczypospolitej, do czego nawoływał król za radą senatu. Szlachta halicka uznała, że nie ma już możliwości wystawiania żołnierza z łanów, stąd poprosiła, aby organizację wyprawy wziął na siebie w całości Andrzej Potocki. Ku zadowoleniu sejmiku starosta nie odmówił i na sejmik obradujący 17 czerwca 1658 roku przyprowadził do Halicza „62 pieszych muszkieterów [...] bene armatos et ornatos i z oficerami”. Przegląd oddziału wypadł pozytywnie, a szlachta obiecywała staroście zwrot kosztów, jeśli środki przewidziane na żołd nie wystarczą ${ }^{34}$. Nie wiadomo jednak, czy muszkieterów Potockiego, uznanych za żołnierzy łanowych ziemi halickiej, włączono do armii koronnej, czy też skierowano do którejś z okolicznych fortec. Sam Potocki na wspomnianym wyżej sejmiku został wybrany jednym z posłów na sejm walny.

Udział starosty Andrzeja Potockiego w organizacji obrony ziemi halickiej wzrósł jeszcze bardziej po 1660 roku, i to mimo rozlicznych obowiązków, które ciążyły nań z racji dowodzenia pułkami komputowymi. Na jego prywatnych wojskach opierała się w zasadzie obrona zamku halickiego. Co prawda w latach 1660-1665 dołączano do nich zwykle 50 żołnierzy zaciąganych z polecenia sejmiku, ale organizacja tego niewielkiego, „suplementowego" oddziału ziemi halickiej i tak spadała zawsze na barki starosty. Czasami wybierano dla niego odrębnego rotmistrza, czasem wyznaczał go Potocki, ale zawsze wykładał własne pieniądze na zadatkowanie żołdu, oczekując na podatki, które napływały z opóźnieniem. Służba owej piechoty samorządowej rozpoczynała się latem (od 1 czerwca, sierpnia lub września), trwała zaledwie jeden kwartał i nigdy nie przedłużano jej na okres zimy ze względu na mniejsze

${ }^{32}$ Ibidem, Uniwersał hetmana S. Potockiego, w obozie pod Kniehyńcami 15 VII 1657 r., s. 203-205; ibidem, Uniwersał tegoż do tych samych, b.m., b.d., s. 208-209. O wysłaniu żołnierzy powiatowych halickich do boku hetmanów świadczy: Uniwersał poborcy W. Dubrawskiego do szlachty halickiej, Halicz, 16 VII 1657 r. (ibidem, s. 212-214).

${ }^{33}$ Laudum ziemi halickiej z 10 IX 1657 r., AGZ, t. 24, s. 137.

${ }^{34}$ Laudum ziemi halickiej z 17 VI 1658 r., AGZ, t. 24, s. 141-142; D. Kupisz, Wyprawy żotnierza tanowego..., s. 224. 
zagrożenie ze strony band rozbójniczych o tej porze roku ${ }^{35}$. W pozostałych trzech kwartałach roku straż na zamku halickim pełnili jedynie ludzie Potockiego.

System doraźnego wspierania starostów niewielkimi zaciągami wojska powiatowego stosowano w wielu województwach ówczesnej Rzeczypospolitej. Oddawanie ich pod komendę starosty niewątpliwie usprawniało chwytanie i sądzenia sprawców rozbojów. Do powiększania owych sił zbrojnych dochodziło jedynie wobec znaczącego zagrożenia ${ }^{36}$. Na przykład w 1664 roku, na wieść o pogorszeniu się sytuacji na Ukrainie, zdecydowano się na sejmiku halickim na łanową wyprawę hajduków, a w 1665 roku, wobec opuszczenia Ukrainy przez armię koronną, na zaciąg 300 jazdy pancernej. Pułkownikiem tegoż zaciągu, służącego od 1 sierpnia 1665 roku, oraz dowódcą jednej z trzech chorągwi pancernych został ponownie Andrzej Potocki, wówczas już chorąży koronny. Obiecał on dołączyć do sił ziemi halickiej swoich 200 dragonów i chorągiew kozacką, a kolejną nadworną chorągiew kozacką przysłał Jan Potocki, wojewoda bracławski, co wzmocniło pułk do około 700 ludzi. Andrzej Potocki pozostał z polecenia Jana Kazimierza „w krajach podolskich”, gdzie miał tłumić wszelkie bunty i ochraniać pogranicze. Z uniwersałów, które wydawał, wynika, że prowadził dość energiczne akcje militarne na obszarze ziemi halickiej i poza nią: zwalczał bandy rabusiów, osłaniał województwo ruskie od wschodu, a rozsyłane przez niego podjazdy docierały aż pod Bracław. Na terenie województwa podolskiego rozbił ze swym pułkiem liczne ugrupowanie opryszków i Kozaków Drozdenki ${ }^{37}$. Za skuteczne działanie przeciw swawolnikom sejmik halicki wynagrodził go kwotą 4000 zł z czopowego ${ }^{38}$.

Po 1665 roku szlachta halicka nie była już w stanie wspierać starostów środkami finansowymi na zaciąg żołnierzy powiatowych ani wyprawami piechurów łanowych. Andrzej Potocki musiał zwalczać opryszków niemal wyłącznie przy pomocy własnych nadwornych wojsk. Nawet jadąc na elekcję w 1669 roku, Haliczanie prosili go o przekazanie 200 nadwornych żołnierzy pod komendę urzędnika odpowiedzialnego za bezpieczeństwo ziemi ${ }^{39}$.

Andrzej Potocki próbował niekiedy odwoływać się do pospolitego ruszenia, ale przynosiło to skutek jedynie w przypadku bardzo poważnego zagrożenia. Za takie

35 D. Kupisz, Wojska powiatowe..., s. 341.

36 W. Kriegseisen, Samorząd szlachecki w Małopolsce w latach 1669-1717, Warszawa 1989, s. 167, 191; D. Kupisz, Wojsko powiatowe jako samoobrona terytorialna województwa sandomierskiego w XVII i na początku XVIII wieku, „Między Wisłą a Pilicą. Studia i Materiały Historyczne” 2006, t. 7, s. 71-72, 81-82; Choragwie powiatowe ziemi chełmskiej w XVI-XVII wieku, „Rocznik Chełmski” 2006, t. 10; idem, Wojsko powiatowe województwa wotyńskiego w XVII wieku, „Naukovyj Visnik Volynskoko Nacjonalnogo Universyteta im. Lesi Ukrainki” 2009, nr 22, s. 182-188; idem, Ochrona pogranicza przez siły zbrojne samorządu województwa ruskiego w drugiej połowie XVII wieku [w:] Urzędy państwowe, organy samorzadowe $i$ kościelne oraz ich kancelarie na polsko-ruskim pograniczu kulturowym i etnicznym od XV do XIX wieku, red. H. Gmiterek, J. Łosowski, Kraków 2010, s. 148-159.

37 D. Kupisz, Wojska powiatowe..., s. 341.

38 Laudum ziemi halickiej z 14 IX 1665 r., AGZ, t. 24, s. 217.

39 Laudum ziemi halickiej z 11 IV 1669 r., AGZ, t. 24, s. 289; A. Prochaska, Samorzad województwa ruskiego $w$ walce z opryszkami, „Rozprawy Wydziału Historyczno-Filologicznego Akademii Umiejętności”, seria 2, t. 24, Kraków 1907, s. 276. 
uznała szlachta halicka wieści o najeździe tatarskim w 1667 roku. Zebrała się na pospolite ruszenie, oddając się pod komendę starosty halickiego. Szacunki niektórych historyków, jakoby dysponował on formacją złożoną aż z 1500 pospolitaków halickich, są z pewnością przesadzone - nawet przy założeniu, że dołączył do nich swych prywatnych żołnierzy. Niemniej jednak na czele szlachty halickiej walczył Potocki jesienią 1667 roku z podjazdami tatarskimi zapuszczającymi się na obszary województwa ruskiego ${ }^{40}$.

Nawet po nominacji na województwo kijowskie Andrzej Potocki nie odmawiał wsparcia poczynaniom wojskowym szlachty halickiej (pozostawał nadal posesorem tamtejszego starostwa grodowego). Organizując wyprawę dymową na wojnę z Turcją w 1673 roku, Haliczanie wybrali rotmistrza jazdy, ale o kapitana dla piechoty niemieckiej wystawianej z dóbr królewskich i duchownych zwrócili się po raz kolejny właśnie do niego ${ }^{41}$. Trzy lata później, wyprawiając na kampanię turecką piechura z 28 dymów, uchwalili, aby zapłacono z nich 120 zł na jednego żołnierza, a organizację oddziału zlecili Andrzejowi Potockiemu. Co prawda dopuszczono możliwość wystawienia żołnierza, ale posesor dóbr był wówczas zobowiązany stawić piechura w barwie określonej przez starostę halickiego ${ }^{42}$.

Hetman polny koronny Dymitr Wiśniowiecki zdecydował, że piechota dymowa ziemi halickiej zostanie przyłączona do regimentu Wacława Dobszyca. Jej organizacja przebiegała jednak opornie, co było niemal regułą w ówczesnych czasach. Wiadomo, że w maju i czerwcu 1676 roku Potocki musiał zarówno zadbać o obronność Halicza zagrożonego najazdem tatarskim, jak i gromadzić piechurów. Narzekał, że poborcy nie przekazują mu obiecanych pieniędzy, a i obywatele, którzy zadeklarowali wystawienie żołnierzy, nie przysyłają ich, przez co musi zbroić poddanymi $\mathrm{z}$ własnych miast ${ }^{43}$.

Zaangażowanie Andrzeja Potockiego w sprawy obrony ziemi halickiej zmalało dopiero w 1682 roku, wraz z cesją tamtejszego starostwa dokonaną przez niego na rzecz syna - Stanisława Potockiego. Nowy starosta nie musiał już tak często łożyć pieniędzy na utrzymanie załogi w zamku halickim, bowiem po odnowieniu konfliktu z Turcją w 1683 roku skierowano tu piechotę koronną. Pozostała ona w Haliczu oraz w Trembowli niemal przez cały okres zmagań z Imperium Osmańskim. Na ziemi halickiej stacjonowały również oddziały jazdy koronnej, toteż odnotowano zaledwie jeden przypadek utrzymywania niewielkiej chorągwi powiatowej przez ziemię halicką w tym okresie. W obliczu planów wyruszenia króla i armii na odsiecz Wiednia

${ }^{40}$ W. Majewski, Podhajce - letnia i jesienna kampania $1667 \mathrm{r}$., „Studia i Materiały do Historii Wojskowości” 1960, t. 6, cz. 1, s. 78-79; A. Przyboś, Potocki Andrzej h. Pilawa [w:] PSB, t. 27, Wrocław-Warszawa-Kraków 1983, s. 774. Na zawyżenie liczebności pospolitego ruszenia halickiego przez tegoż autora zwracał już uwagę L.A. Wierzbicki, op. cit., s. 105. Niewykluczone, że ten sam Potocki stanął na czele pospolitego ruszenia województwa kijowskiego w $1671 \mathrm{r}$ z z racji sprawowania wówczas urzędu tamtejszego wojewody, ibidem, s. 254.

${ }^{41}$ Laudum ziemi halickiej z 5 V 1673 r., AGZ, t. 24, s. 352.

${ }^{42}$ Laudum ziemi halickiej z 12 V 1676 r., AGZ, t. 24, s. 400.

${ }^{43}$ CPAHUL, fond 5, op. 1, nr 177, Uniwersał D. Wiśniowieckiego, w Krakowie 20 IV 1676 r., s. 673-674; ibidem, Manifestacje P. Lachowskiego w imieniu A. Potockiego z 8 i 16 VI 1676 r., s. 821, $850-851$. 
szlachta zebrana w Haliczu 31 maja 1683 roku uchwaliła podatki na 30 koni lekkiej jazdy. Zaciągał ją starosta halicki Stanisław Potocki, który wyznaczył porucznika dla tych żołnierzy ${ }^{44}$, bowiem sam wyruszył na wyprawę wiedeńską, dowodząc pułkiem swego ojca ${ }^{45}$.

Poza trzema wspomnianymi powyżej Potockimi, reprezentantami tej samej rodziny i starostami halickim z ojca na syna, dowódcami sił zbrojnych samorządu szlacheckiego ziemi halickiej zostawali także inni Pilawici. Byli to oczywiście bliżsi lub dalsi krewni obydwu Stanisławów i Andrzeja, piastujący z reguły urzędy w ziemi halickiej. Podczas bezkrólewia po śmierci Władysława IV podkomorzy halicki Jan Teodoryk Potocki (przyrodni brat Stanisława Rewery) organizował popis szlachty halickiej. We wrześniu 1648 roku gromadził ją w ramach pospolitego ruszenia elekcyjnego na Mogielnickim Polu ${ }^{46}$. Jak już wspomniano, od lipca do września następnego roku dowodził pospolitym ruszeniem ziemi halickiej. Ochraniał powierzone mu terytorium podczas ekspedycji halickiego pułku powiatowego pod Zborów, a nawet jakiś czas po powrocie żołnierzy z obozu królewskiego ${ }^{47}$.

Na przełomie 1657 i 1658 roku Jan Teodoryk Potocki uczestniczył z ramienia monarchy $\mathrm{w}$ rokowaniach $\mathrm{z}$ komisarzami hospodara mołdawskiego. Miały one doprowadzić do zapewnienia pokoju na obszarach pogranicznych i wypłacenia szlachcie odszkodowań za szkody wyrządzane przez działające tu bandy zbójeckie. Jak było do przewidzenia, rokowania nie przyniosły spodziewanego skutku i wiosną 1658 roku podkomorzy włączył się $\mathrm{w}$ organizację piechoty łanowej mającej $\mathrm{w}$ miejsce pospolitego ruszenia chronić ziemię halicką „od swawoli opryszkowskiej”. Ponaglał uniwersałami szlachtę, nakazując jej wystawienie z czterech łanów „,chłopa ze strzelbą" i bronią sieczną pod komendę rotmistrza Macieja Przesieckiego. Oddział ten, sformowany na ćwierć roku, ochraniał pogranicze z Mołdawią i Siedmiogrodem oraz zwalczał bandy zbójeckie na obszarze powiatów trembowelskiego, kołomyjskiego i halickiego $0^{48}$. Wiadomo, że działał latem 1658 roku, a wsparła go chorągiew wojewodzica bracławskiego Jana Potockiego, który przeszedłszy wraz z nią w pościgu za opryszkami granicę mołdawską, dostał się nieopatrznie do niewoli ${ }^{49}$. Dwa lata później Haliczanie uchwalili lokalne pospolite ruszenie, którym dowodził wspomniany już Jan Teodoryk Potocki. Pełnił wówczas z ramienia sejmiku funkcję pułkownika ziemi halickiej uprawnionego do zwoływania szlachty pod broń w przypadku nasilenia

${ }^{44}$ Laudum ziemi halickiej z 31 V 1683 r., AGZ, t. 24, s. 443; CPAHUL, fond 5, op. 1, nr 186, Uniwersał S. Potockiego do miast i miasteczek ziemi halickiej, na zamku halickim z 2 VI 1683 r., s. 465-466.

${ }^{45}$ A. Przyboś, op. cit., s. 775.

${ }^{46}$ CPAHUL, fond 17, op. 1, nr 131, Uniwersał J.T. Potockiego, Warszawa, 3 VIII 1648 r., s. $353-$ 341; ibidem, Uniwersał tegoż, b.m. b.d. [1648], s. 400-401.

${ }^{47}$ CPAHUL, fond 5, op. 1, nr 141, Atestacja J.T. Potockiego dla M. Bystrzyjowskiego, obóz pod Haliczem, 2 IX 1649 r., s. 1882-1883.

48 Ibidem, nr 148, Uniwersał komisarzy królewskich, XII 1657 r., s. 400-401; ibidem, Uniwersał J.T. Potockiego, w Gwoźdźcu 12 V 1658 r., s. 880-882.

${ }^{49}$ Laudum ziemi halickiej z 9 IX 1658 r., AGZ, t. 24, s. 146. 
bandytyzmu lub innych zagrożeń ${ }^{50}$. Z kolei wiosną 1668 roku jednym z rotmistrzów halickiego pospolitego ruszenia został Bogusław Potocki ${ }^{51}$.

Wspomniany wyżej Bogusław Potocki zaangażował się w 1671 roku w organizację wojska powiatowego ziemi halickiej. W myśl postanowień konstytucji sejmowych sejmik halicki uchwalił wówczas wystawienie trzech chorągwi po 80 koni w celu posiłkowania armii koronnej. Każda chorągiew miała być opłacona przez jeden powiat, a tą z kołomyjskiego miał osobiście dowodzić Bogusław Potocki. Ostatecznie jednak szlachta halicka zmniejszyła sobie obciążenie o połowę, uchwalając dwie chorągwie po 60 koni jazdy pancernej. Jedną z nich zaciągał wspomniany Potocki, koncentrując żołnierzy w Sołotwinie. Służbę zamierzano mu liczyć od 1 października, przestrzegając, aby przyjmował na służbę „szlachtę dobrą, nie Wołochów”. Wobec protestacji części szlachty halickiej i zamieszania $\mathrm{z}$ formowaniem podobnych jednostek w innych ziemiach i województwach przełożono realizację uchwały do wiosny $1672 \mathrm{roku}^{52}$. Nie wiadomo dokładnie, kiedy Bogusław Potocki zaciągał ludzi, ale jego chorągiew istniała, wspierając hetmana Jana Sobieskiego i konfederatów szczebrzeszyńskich ${ }^{53}$. Została przejęta później na żołd państwowy i brała udział w kampanii chocimskiej w 1673 roku $^{54}$.

Na zakończenie warto zasygnalizować, że Potoccy herbu Pilawa włączali się w organizowanie wojsk powiatowych oraz wypraw łanowych i dymowych także w innych województwach. W 1667 roku podstoli koronny Szczęsny (Feliks) Potocki, syn Stanisława Rewery, a brat starosty halickiego Andrzeja, został wybrany pułkownikiem sił zbrojnych województwa bełskiego (także on pod koniec życia został hetmanem). Przekształcił wówczas na własny koszt swą chorągiew komputową z kozackiej w husarską, a kozacką powiatową zdołał w sierpniu tego samego roku włączyć do komputu. Wiadomo ponadto, że wziął udział w kampanii podhajeckiej pod komendą hetmana Jana Sobieskiego ${ }^{55}$. Jan Potocki, wojewoda bracławski, pojawił się wśród szlachty zebranej jesienią 1672 roku na pospolite ruszenie pod Gołębiem. Planowano posłanie go na czele jednego z podjazdów, który w październiku miał dokonać dalekiego rekonesansu w rejon Podhajec. Wydaje się jednak, że plany owe nie zostały zrealizowane ${ }^{56}$.

${ }^{50}$ CPAHUL, fond 17, op. 1, nr 135, Uniwersał pułkownika pospolitego ruszenia ziemi halickiej J.T. Potockiego, Halicz, 15 IX 1660 r., s. 184-185.

${ }^{51}$ Laudum ziemi halickiej z 9 V 1668 r., AGZ, t. 24, s. 267.

${ }^{52}$ Laudum 27 II 1671 r., AGZ, t. 24, s. 316; Laudum 22 IX 1671 r., AGZ, t. 24, s. 327; Instrukcya sejmiku posłom na sejm walny, 15 XII 1671 r., AGZ, t. 24, s. 331; J. Kaniew ski, Sejmiki koronne wobec problemów wewnętrznych za panowania Michała Korybuta Wiśniowieckiego (1669-1673), Katowice 2014, s. 561.

${ }_{53}$ Z. Hundert, Między buława a tronem. Wojsko koronne w walce malkontentów z ugrupowaniem dworskim w latach 1669-1673, Oświęcim 2014, s. 370-371; idem, Zaciężne wojsko powiatowe sejmiku wiszeńskiego województwa ruskiego 1671-1673 oraz jego rola w działaniach wojskowych i politycznych Jana Sobieskiego, „Przegląd Historyczny” 2017, t. 108, z. 4, s. 662-663.

${ }^{54}$ Ibidem, s. 663, przyp. 123; CPAHUL, fond 5, op. 1, nr 174, Protestacja przeciw chorągwi królewskiej B. Potockiego, 31 VIII 1673 r., s. 1352; ibidem, nr 175, Asygnacja J.A. Morsztyna na wybieranie żołdu dla chorągwi B. Potockiego, Warszawa, 13 IX 1672 r., s. 978-979.

55 D. Kupisz, Wojska powiatowe..., s. 279.

${ }^{56}$ L.A. Wierzbicki, op. cit., s. 261. 
Z kolei podkomorzy bracławski Jan Karol Potocki zwoływał Bracławian pod Włodzimierz jesienią 1670 roku i prawdopodobnie został duktorem tamtejszego pospolitego ruszenia $^{57}$. Z pewnością podobnych przykładów można odnaleźć w źródłach więcej, nie ulega jednak wątpliwości, że dominującym obszarem działalności Potockich była ziemia halicka.

Zaangażowanie Potockich w organizowanie sił zbrojnych samorządów szlacheckich było zwykle jednym z wielu przejawów ich szerokiej działalności wojskowej (niekiedy jedynie ubocznym). Miało z pewnością różnorakie podłoże. Na ziemi halickiej wynikało z posiadania tu przez nich znacznych dóbr i dzierżenia miejscowych starostw, które należało ochraniać. Nie był to z pewnością jedyny powód. Dowodzenie wojskiem powiatowym, wyprawami czy pospolitym ruszeniem potwierdzało ich znaczne wpływy polityczne wśród szlachty, a także ułatwiało im tworzenie i utrzymywanie systemu klientalnego. Nie ulega wątpliwości, że taka sytuacja była również wygodna dla szlachty halickiej, gdyż pozwalała na przerzucenie części wysiłku organizacyjnego, a nawet kosztów utrzymania wojska samorządowego na barki przedstawicieli zasobnej rodziny. Nie bez znaczenia było też doświadczenie wojskowe, którym mogli się poszczycić wszyscy Potoccy. Sejmik angażował ich więc wielokrotnie w organizację sił zbrojnych, powierzając przy każdej nadarzającej się okazji stanowiska rotmistrzów, pułkowników bądź regimentarzy.

\section{BIBLIOGRAFIA}

\section{Źródła rękopiśmienne}

Archiwum Narodowe w Krakowie

Zbiór Rusieckich, sygn. 41

Biblioteka Naukowa Polskiej Akademii Umiejętności i Polskiej Akademii Nauk w Krakowie rkps 1051

Центральний державний історичний архів України, Львів [Centralne Państwowe Archiwum Historyczne Ukrainy we Lwowie (CPAHUL)]

Fond 5 (Księgi grodzkie halickie), op. 1, nr 141, 142, 147, 148, 172, 174, 175, 177, 186

Fond 17 (Księgi grodzkie trembowelskie), op. 1, nr 131, 135

\section{Źródła wydane drukiem}

Akta grodzkie i ziemskie z czasów Rzeczypospolitej Polskiej z archiwum tak zwanego bernardyńskiego we Lwowie, t. 24: Lauda sejmikowe halickie 1575-1695, wyd. A. Prochaska, Lwów 1931.

${ }^{57}$ Ibidem, s. $137-138,356$. 
Jakuba Michałowskiego, wojskiego lubelskiego a później kasztelana bieckiego księga pamiętnicza z dawnego rękopisma będacego własnościa Ludwika hr. Morsztyna, wyd. A.Z. Helcel, Kraków 1864.

Relacje wojenne z pierwszych lat walk polsko-kozackich powstania Bohdana Chmielnickiego, okresu „Ogniem i mieczem” (1648-1651), oprac. M. Nagielski, Warszawa 1999.

Sprawy i rzeczy ukraińskie. Materiały do dziejów kozaczyzny i hajdamaczyzny, wyd. F. Rawita-Gawroński, Lwów 1914.

Volumina Constitutionum, t. 4, vol. 1, oprac. S. Grodziski, M. Kwiecień, K. Fokt, Warszawa 2015.

\section{Opracowania}

Borowiak A., Wojsko powiatowe przed kampania piławiecka 1648 roku [w:] Studia nad staropolska sztuka wojenna, t. 2, red. Z. Hundert, Oświęcim 2013, s. 129-160.

Ciesielski T., Wyprawa łanowa 1653 r., ,Zeszyty Naukowe Wyższej Szkoły Pedagogicznej im. Powstańców Śląskich w Opolu. Historia” 1994, t. 30, s. 47-80.

Czołow ski A., Z dziejów chmielniczyzny na Podkarpaciu [w:] Księga pamiątkowa ku czci Władysława Abrahama, t. 2, Lwów 1931, s. 387-400.

Gerlach J., Żotnierz łanowy $i$ dymowy w Polsce feudalnej, „Sprawozdania Towarzystwa Naukowego w Toruniu" 1952, nr 6, z. 1-4, s. 73-80.

Hundert Z., Między buława a tronem. Wojsko koronne w walce malkontentów z ugrupowaniem dworskim w latach 1669-1673, Oświęcim 2014.

Hundert Z., Zaciężne wojsko powiatowe sejmiku wiszeńskiego województwa ruskiego 1671-1673 oraz jego rola $w$ działaniach wojskowych i politycznych Jana Sobieskiego, „Przegląd Historyczny” 2017, t. 108, z. 4, s. 641-671.

Kaniewski J., Sejmiki koronne wobec problemów wewnętrznych za panowania Michała Korybuta Wiśniowieckiego (1669-1673), Katowice 2014.

Kriegs e is en W., Samorzad szlachecki w Małopolsce w latach 1669-1717, Warszawa 1989.

Kupisz D., Choragwie powiatowe ziemi chetmskiej w XVI-XVII wieku, ,Rocznik Chełmski” 2006, t. 10, s. 57-72.

Kupis z D., Ochrona pogranicza przez sity zbrojne samorzadu województwa ruskiego w drugiej połowie XVII wieku [w:] Urzędy państwowe, organy samorządowe i kościelne oraz ich kancelarie na polsko-ruskim pograniczu kulturowym i etnicznym od XV do XIX wieku, red. H. Gmiterek, J. Łosowski, Kraków 2010, s. 148-159.

Kupisz D., Wojska powiatowe samorzadów Małopolski i Rusi Czerwonej w latach 1572 1717, Lublin 2008.

Kupisz D., Wojsko powiatowe jako samoobrona terytorialna województwa sandomierskiego w XVII i na początku XVIII wieku, „Między Wisłą a Pilicą. Studia i Materiały Historyczne" 2006, t. 7, s. 71-84.

Kupisz D., Wojsko powiatowe województwa wołyńskiego w XVII wieku, „Naukovyj Visnik Volynskoko Nacjonalnogo Universyteta im. Lesi Ukrainki” 2009, nr 22, s. 182-188.

Kupisz D., Wyprawy żotnierza łanowego w Koronie w czasach Jana Kazimierza, Warszawa 2018.

Łoziński W., Prawem i lewem. Obyczaje na Czerwonej Rusi w pierwszej połowie XVII wieku, t. 1, Kraków 1957.

Majewski W., Podhajce - letnia i jesienna kampania 1667 roku, „Studia i Materiały do Historii Wojskowości” 1960, t. 6, cz. 1, s. 70-98. 
Nagielski M., Potocki Jan h. Pilawa [w:] Polski słownik biograficzny, t. 28, Wrocław-Warszawa-Kraków 1984-1985, s. 32.

Prochaska A., Samorząd województwa ruskiego w walce z opryszkami, „Rozprawy Wydziału Historyczno-Filologicznego Akademii Umiejętności”, seria 2, t. 24, Kraków 1907.

Przyboś A., Potocki Andrzej h. Pilawa [w:] Polski słownik biograficzny, t. 27, WrocławWarszawa-Kraków 1983, s. 771-774.

Przyboś A., Potocki Stanisław zwany Rewera [w:] Polski słownik biograficzny, t. 28, Wrocław-Warszawa-Kraków 1984-1985, s. 142-148.

Tomašivskij S., Narodni ruchy v halickij Rusy 1648 g, Lviv 1898.

Wierzbicki L.A., Pospolite ruszenie w Polsce w drugiej połowie XVII wieku. Ostatnie wyprawy z lat 1670-1672, Lublin 2011.

Wimmer J., Wojsko polskie w drugiej połowie XVII wieku, Warszawa 1965. 